\title{
Cryobacterium psychrophilum gen. nov., sp. nov., nom. rev., comb. nov., an Obligately Psychrophilic Actinomycete To Accommodate "Curtobacterium psychrophilum" Inoue and Komagata 1976
}

\author{
KEN-ICHIRO SUZUKI, ${ }^{1 *}$ JUNKO SASAKI,${ }^{1}$ MASAKAZU URAMOTO,${ }^{2}$ TAKASHI NAKASE, ${ }^{1}$ \\ AND KAZUO KOMAGATA ${ }^{3}$ \\ Japan Collection of Microorganisms, The Institute of Physical and Chemical Research (RIKEN), Wako-shi, \\ Saitama 351-01, ${ }^{1}$ Department of Agriculture, Tamagawa University, Machida, Tokyo 192, ${ }^{2}$ and \\ Tokyo University of Agriculture, Setagaya-ku, Tokyo $156,{ }^{3}$ Japan
}

\begin{abstract}
"Curtobacterium psychrophilum," proposed by Inoue and Komagata in 1976, is a psychrophilic gram-positive irregular rod isolated from Antarctic soil. This organism grew optimally at 9 to $12^{\circ} \mathrm{C}$ and did not grow at higher than $18^{\circ} \mathrm{C}$. Chemotaxonomic characteristics of this organism were the presence of 2,4-diaminobutyric acid in the cell wall and menaquinone-10 as the predominant respiratory quinone. The cellular fatty acid profile, which contained a significant amount of an anteiso-branched monounsaturated acid, 12-methyl tetradecenoic acid, was a distinctive characteristic of this organism and was reasonable for adaptation to low temperature. Phylogenetic analysis based on $16 \mathrm{~S}$ ribosomal DNA sequences revealed that this organism was positioned at a separate branch in the family Microbacteriaceae, actinomycetes with group B peptidoglycan. We propose the name Cryobacterium psychrophilum gen. nov., sp. nov. for this organism. The type strain is JCM 1463 (=IAM $12024=$ ATCC $43563=$ IFO $15735=$ NCIMB 2068).
\end{abstract}

In the course of an ecological study of microorganisms in Antarctica, Inoue isolated some obligately psychrophilic bacteria from soil in Antarctica (8), and the name "Curtobacterium psychrophilum" was proposed by Inoue and Komagata (9) in 1976 for an aerobic gram-positive pleomorphic rod. This bacterium grew optimally from 9 to $12^{\circ} \mathrm{C}$ and did not grow at temperatures higher than $18^{\circ} \mathrm{C}$. The organism was classified in the genus Curtobacterium because of the presence of ornithine in the cell wall, the $66.5 \mathrm{~mol} \% \mathrm{G}+\mathrm{C}$ content of the DNA, and the pleomorphic cell morphology. However, the name has not been validly published yet, and its further chemotaxonomic features have not been reported. Its position in the bacterial phylogenetic tree remained to be studied.

In the present study, we found a significant amount of anteiso-branched monounsaturated fatty acid, which has been generally reported to be at not more than a trace amount in bacterial cells $(12,16)$, except for in a plant pathogenic bacterium (23). Therefore, the cellular fatty acid composition of this organism is of interest in terms of the effect of the cultivation temperature, considering the psychrophilic property, as well as a chemotaxonomic marker.

We also found 2,4-diaminobutyric acid (DAB) in the cell wall peptidoglycan instead of ornithine, which was reported in the original paper (9). This paper deals with the taxonomy of "C. psychrophilum" and the proposal of the name Cryobacterium psychrophilum gen. nov., sp. nov., nom. rev., comb. nov.

\section{MATERIALS AND METHODS}

Bacterial strains studied and cultivation. "C. psychrophilum" JCM $1463^{\mathrm{T}}$ originated from Inoue strain 27-O-b isolated from soil in Antarctica (9). This is the proposed monotype strain of this invalid species. This bacterium was cultivated for 7 days at $10^{\circ} \mathrm{C}$ on $\mathrm{R}$ agar (32) unless otherwise stated. Curtobacterium

* Corresponding author. Mailing address: Japan Collection of Microorganisms, The Institute of Physical and Chemical Research (RIKEN), Wako-shi, Saitama 351-01, Japan. Phone: 81 (48) 467-9559. Fax: 81 (48) 462-4617. E-mail: ksuzuki@ulmus.riken.go.jp. albidum JCM $1344^{\mathrm{T}}$, Curtobacterium citreum JCM $1346^{\mathrm{T}}$, and Curtobacterium pusillum $\mathrm{JCM} 1350^{\mathrm{T}}$ were cultivated at 10 and $17^{\circ} \mathrm{C}$ on R agar for comparison of the cellular fatty acid compositions.

Chemotaxonomy. The amino acid composition of the cell wall peptidoglycan, the cell wall acyl type, and the isoprenoid quinones were determined by methods described previously (15). The cell wall sugar profile was determined by highperformance liquid chromatography (HPLC) with derivatization as described by Takeuchi and Yokota (28). The polar lipid profile was determined by the integrated method for lipid analysis described by Minnikin et al. (17).

Cellular fatty acid analysis. Fatty acid methyl esters were liberated from $50 \mathrm{mg}$ of lyophilized cells by methanolysis at $100^{\circ} \mathrm{C}$ for $3 \mathrm{~h}$ with $3 \mathrm{ml}$ of $5 \%$ methanolic $\mathrm{HCl}$ and were extracted three times each with $3 \mathrm{ml}$ of petroleum ether $(15,25)$ Hydrogenation of unsaturated fatty acids was carried out by bubbling of hydrogen gas in the presence of platinum black for $60 \mathrm{~min}$. A Shimadzu GC-14A gas chromatograph with a fused silica capillary column, OV-1 $(0.25 \mathrm{~mm}$ by $25 \mathrm{~m}$ Nihon Chromato Co., Tokyo, Japan), was used for the separation of fatty acid methyl esters. The temperature of the injection port and detector block was $250^{\circ} \mathrm{C}$; the column oven was kept at $180^{\circ} \mathrm{C}$. Helium was used as the carrier gas. Gas-liquid chromatography-mass spectrometry (GC-MS) was carried out with a Shimadzu gas-liquid chromatograph-mass spectrometer, model QP-1000. The conditions for GC were the same as those mentioned above. For the MS, the ionizing current was $60 \mathrm{~mA}$, the electron-accelerating voltage was $70 \mathrm{eV}$, and the ion-source temperature was $250^{\circ} \mathrm{C}$. Standard methyl esters of 12 -methyl tetradecanoic (a-15:0), 14-methyl hexadecanoic (a-17:0), 12-methyl tridecanoic (i-14: 0 ), 13-methyl tetradecanoic (i-15:0), 14-methyl pentadecanoic (i-16:0), and 15 methyl hexadecanoic (i-17:0) acids were purchased from GL Sciences, Inc. (Tokyo, Japan), as were those of straight-chain acids.

Biochemical and physiological characteristics. Acid production from $28 \mathrm{car}-$ bohydrates, assimilation of 16 organic acids, nitrate reduction, and hydrolysis of DNA, starch, gelatin, and casein were tested by the methods described by Yamada and Komagata (32).

DNA base composition. DNA was extracted from the biomass by the methods of Saito and Miura (20) with some modifications. DNA base composition was determined by the method of Tamaoka and Komagata (30) by HPLC after enzymatic digestion of DNA to deoxyribonucleosides. An equimolar mixture of four deoxyribonucleotides in the Yamasa GC kit (Yamasa Shoyu Co., Ltd., Choshi, Japan) was used as the quantitative standard.

Phylogenetic analysis. The $16 \mathrm{~S}$ ribosomal DNA (rDNA) sequence of " $C$. psychrophilum" JCM $1463^{\mathrm{T}}$ was determined by a method previously described (26) and deposited in DDBJ under accession number D45058. Nucleotide substitution rates ( $K_{\text {nuc }}$ values) were calculated (13), and the phylogenetic tree was constructed by the neighbor-joining method (21). The topology of trees was evaluated by bootstrap analysis of the sequence data with CLUSTAL W software (31). This sequence was aligned with the following published sequences from DDBJ, GenBank, and EMBL: Agrococcus jenensis DSM 9580 ${ }^{\mathrm{T}}$, X92492; Agro myces cerinus subsp. cerinus JCM 9083' ${ }^{\mathrm{T}}$, D45060; Agromyces fucosus subsp. 


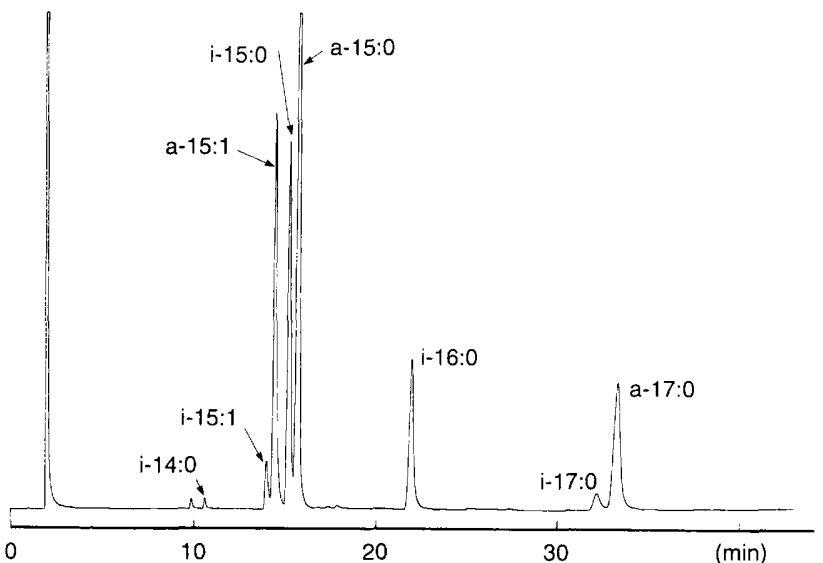

FIG. 1. Gas-liquid chromatogram of cellular fatty acid methyl esters extracted from $C$. psychrophilum JCM $1463^{\mathrm{T}}$. The fatty acids used are abbreviated as follows: i-14:0, 12-methyl tridecanoic acid; i-15:1, 13-methyl tetradecenoic acid; a-15:1, 12-methyl tetradecenoic acid; i-15:0, 13-methyl tetradecanoic acid a-15:0, 12-methyl tetradecanoic acid; i-16:0, 14-methyl pentadecanoic acid; i-17:0, 15-methyl hexadecanoic acid; a-17:0, 14-methyl hexadecanoic acid.

hippuratus JCM 9085 ${ }^{\mathrm{T}}$, D45061; Agromyces mediolanus DSM 20152 ${ }^{\mathrm{T}}$, X77449; Agromyces ramosus DSM 43045 ${ }^{\mathrm{T}}$, X77447; Aureobacterium barkeri DSM $20145^{\mathrm{T}}$, X77446; Aureobacterium testaceum DSM 20166 ${ }^{\mathrm{T}}$, X77445; "Brevibacterium helvolum" DSM 20419, X77440; Clavibacter michiganensis subsp. insidiosus JCM 1369, D45051; Clavibacter michiganensis subsp. michiganensis DSM $46364^{\mathrm{T}}$, X77435; Clavibacter michiganensis subsp. nebraskensis DSM 7483T, X77434 Clavibacter xyli subsp. cynodontis, M60935; "Corynebacterium aquaticum" JCM 1368, D45057; Curtobacterium citreum DSM 20528 ${ }^{\mathrm{T}}$, X77436; Curtobacterium luteum DSM 20542 , X77437; Leucobacter komagatae JCM 9414 ${ }^{\mathrm{T}}$, D45063; Microbacterium imperiale DSM $20530^{\mathrm{T}}$, X77442; Microbacterium lacticum DSM $20427^{\mathrm{T}}$, X77441; Rathayibacter rathayi DSM 7485', X77439; and Rathayibacter tritici DSM $7486^{\mathrm{T}}, \mathrm{X} 77438$. Brevibacterium linens DSM $20425^{\mathrm{T}}(\mathrm{X} 77451)$ was used as an out-group organism.

\section{RESULTS}

Morphological characteristics. Cells of "C. psychrophilum" JCM $1463^{\mathrm{T}}$ were gram-positive, non-endospore-forming irregular rods. Cell size was 0.5 to $0.7 \mu \mathrm{m}$ by 1.0 to $1.8 \mu \mathrm{m}$ in the culture on $\mathrm{R}$ agar for 5 days at $10^{\circ} \mathrm{C}$. Motility was not observed.

Chemotaxonomy. The peptidoglycan hydrolysate contained $\mathrm{DAB}$, glycine, glutamic acid, and alanine. The molar ratio of glutamic acid to alanine to glycine to $\mathrm{DAB}$ in the cell wall peptidoglycan was 1.0:0.6:1.0:1.3. The cell wall acyl type was acetyl. Fucose and rhamnose were found in the cell wall hydrolysate. The major isoprenoid quinone was menaquinone (MK), and the composition was MK-10 (50.4\%), MK-11 (17.3\%), MK-8 (14.2\%), and MK-9 (11.2\%). Diphosphatidylglycerol, phosphatidylglycerol, and one glycolipid were detected by thin-layer chromatography and specific visualization.

Cellular fatty acid composition. The gas chromatogram of the fatty acid methyl esters from the cells of " $C$. psychrophilum" JCM $1463^{\mathrm{T}}$ cultivated at $10^{\circ} \mathrm{C}$ for 7 days is shown in Fig. 1. The predominant peaks corresponding to the standard compounds were a-15:0, i-15:0, a-17:0, and i-16:0 (Table 1). The identities of these peaks were also confirmed by MS. In addition to those, a significant amount of 12-methyl tetradecenoic acid (a-15:1) was found. The mass spectrum of this peak was considered to be that of methyl pentadecenoate because of the relatively large peak of 55 and the presence of $\mathrm{M}-32, \mathrm{M}-$ 74 , and $254\left(\mathrm{M}^{+}\right)$, in spite of the base peak at 74 . It is true that the methyl esters of anteiso-branched, iso-branched, and straight-chain saturated fatty acids with the same numbers of carbon were not distinguished from one another only by their mass spectra. However, the peak disappeared by hydrogenation, and the ratio of the acid in the cellular fatty acids was accurately added to that of the corresponding saturated fatty acid, a-15:0. Therefore the peak was identified as a-15:1. The peak of 13-methyl tetradecenoic acid (i-15:1) was also identified by the same procedure.

Effect of cultivation temperature on cellular fatty acid composition. The cellular fatty acid compositions of " $C$. psychrophilum" JCM $1463^{\mathrm{T}}$ cultivated at different temperatures were examined (Table 1). The proportion of a-15:1 was increased in the cells grown at the lower temperature. The cellular fatty acid compositions of some mesophilic Curtobacterium strains grown at 10 and $17^{\circ} \mathrm{C}$ were examined for comparison as shown in Table 1 . They are reported to grow optimally at 25 to $30^{\circ} \mathrm{C}(7,14)$ and did not produce enough biomass for fatty acid analysis below $10^{\circ} \mathrm{C}$. Although a small amount of a-15:1 was detected, they did not show the same composition as "C. psychrophilum" JCM $1463^{\mathrm{T}}$.

Biochemical and physiological characteristics. The results of tests to determine biochemical and physiological characteristics are shown in Table 2.

TABLE 1. Effect of growth temperature on the cellular fatty acid composition of C. psychrophilum and some mesophilic Curtobacterium strains

\begin{tabular}{|c|c|c|c|c|c|c|c|c|c|c|c|c|}
\hline \multirow{3}{*}{ Strain } & \multirow{3}{*}{$\begin{array}{c}\text { Growth } \\
\text { temp } \\
\left({ }^{\circ} \mathrm{C}\right)\end{array}$} & \multicolumn{11}{|c|}{ Fatty acid composition $(\%)^{a}$} \\
\hline & & \multicolumn{4}{|c|}{ Monounsaturated } & \multicolumn{7}{|c|}{ Saturated } \\
\hline & & a- $-15: 1$ & a-17:1 & $\mathrm{i}-15: 1$ & $\mathrm{i}-16: 1$ & $a-15: 0$ & $\mathrm{a}-17: 0$ & $\mathrm{i}-14: 0$ & $i-15: 0$ & $\mathrm{i}-16: 0$ & $\mathrm{i}-17: 0$ & ch-17:0 \\
\hline \multirow[t]{4}{*}{ Cryobacterium psychrophilum JCM $1463^{\mathrm{T}}$} & 17 & 4.4 & & 0.8 & & 50.9 & 15.0 & 0.7 & 16.9 & 9.4 & 1.7 & \\
\hline & 10 & 19.8 & & 2.3 & & 33.6 & 13.4 & & 18.4 & 10.2 & 1.7 & \\
\hline & 8 & 22.3 & & 1.8 & & 34.3 & 14.6 & & 16.5 & 8.3 & 1.3 & \\
\hline & 4 & 26.3 & & 1.8 & & 31.2 & 11.2 & & 18.5 & 8.4 & 1.1 & \\
\hline \multirow[t]{2}{*}{ Curtobacterium albidum JCM $1344^{\mathrm{T}}$} & 17 & 1.9 & & & & 67.3 & 20.7 & 1.7 & 1.9 & 8.3 & & \\
\hline & 10 & 6.3 & $\operatorname{tr}$ & & & 67.0 & 14.1 & 1.9 & 2.1 & & & \\
\hline \multirow[t]{2}{*}{ Curtobacterium citreum JCM $1346^{\mathrm{T}}$} & 17 & $\operatorname{tr}$ & & & & 60.2 & 23.8 & 1.4 & 1.7 & 11.4 & & \\
\hline & 10 & 8.0 & 3.3 & & 3.6 & 51.8 & 21.1 & 1.3 & 0.8 & 10.0 & & \\
\hline \multirow[t]{2}{*}{ Curtobacterium pusillum JCM $1350^{\mathrm{T}}$} & 17 & & & & & 46.0 & 25.6 & 0.4 & 3.3 & 6.3 & & 18.5 \\
\hline & 10 & 1.7 & & & & 54.9 & 23.8 & 0.3 & 2.2 & 2.4 & & 14.7 \\
\hline
\end{tabular}

${ }^{a}$ a, anteiso-branched acid; i, iso-branched acid; ch, $\omega$-cyclohexyl acid; tr, trace amount. 
TABLE 2. Physiological and biochemical characteristics of $C$. psychrophilum JCM $1463^{\mathrm{T}}$

\begin{tabular}{|c|c|}
\hline Characteristic & Reaction $^{a}$ \\
\hline \multicolumn{2}{|l|}{ Acid from: } \\
\hline \multicolumn{2}{|c|}{ Amygdalin } \\
\hline \multicolumn{2}{|c|}{ L-Arabinose } \\
\hline \multicolumn{2}{|c|}{ 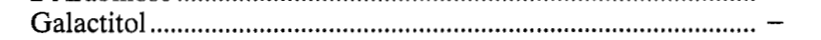 } \\
\hline \multicolumn{2}{|c|}{ 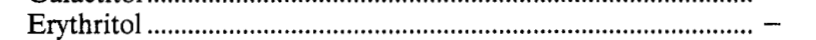 } \\
\hline \multicolumn{2}{|c|}{ Esculin } \\
\hline \multicolumn{2}{|c|}{ Fructose } \\
\hline \multicolumn{2}{|c|}{ 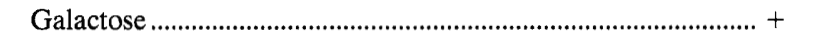 } \\
\hline \multicolumn{2}{|c|}{ 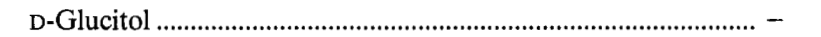 } \\
\hline \multicolumn{2}{|c|}{ 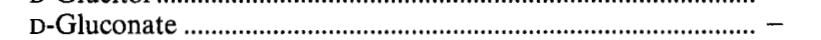 } \\
\hline \multicolumn{2}{|c|}{ Glucose } \\
\hline \multicolumn{2}{|c|}{ 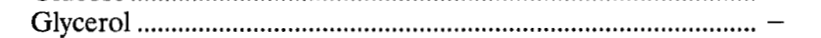 } \\
\hline \multicolumn{2}{|c|}{ 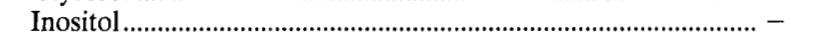 } \\
\hline \multicolumn{2}{|c|}{ 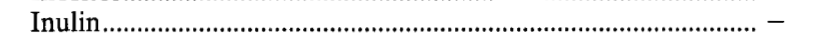 } \\
\hline \multicolumn{2}{|c|}{ D-Lactose } \\
\hline \multicolumn{2}{|c|}{ 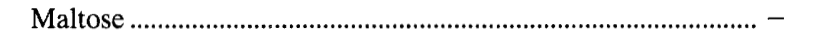 } \\
\hline \multicolumn{2}{|c|}{ 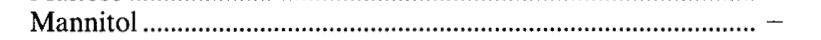 } \\
\hline \multicolumn{2}{|c|}{ 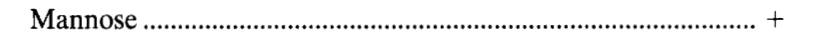 } \\
\hline \multicolumn{2}{|c|}{ 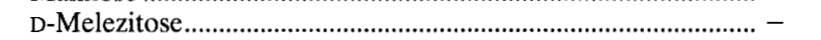 } \\
\hline \multicolumn{2}{|c|}{ Melibiose } \\
\hline \multicolumn{2}{|c|}{ 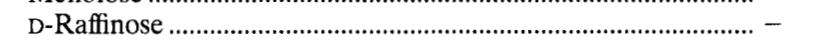 } \\
\hline \multicolumn{2}{|c|}{ 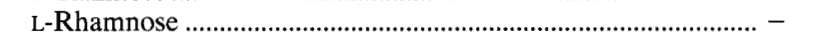 } \\
\hline Ribitol ........... & $\ldots . . .$. \\
\hline Ribose ...... & ... \\
\hline Salicin....... & $\ldots \ldots$. \\
\hline Sucrose...... & $\ldots \ldots+$ \\
\hline Tagatose ..... & $\ldots \ldots$. \\
\hline D-Trehalose &.. \\
\hline D-Xylose... &.. \\
\hline Assimilation & \\
\hline$n$-Butyrate... & $\ldots .$. \\
\hline Citrate ......... & $\ldots . . .-$ \\
\hline Formate.. & $\ldots \ldots$. \\
\hline Fumarate. & ... + \\
\hline Glut & ..... - \\
\hline Glyoxylate... & ......... \\
\hline Tippurate ... & .......- \\
\hline actate & $\ldots \ldots .+$ \\
\hline Malate....... & + \\
\hline ate.... & $\ldots$. \\
\hline Nicotinate... & …..... - \\
\hline Propionate. & $\ldots \ldots .+$ \\
\hline yruv &..+ \\
\hline uccinate.. & + \\
\hline Tartrate....... & ........- \\
\hline Uric acid ...... & $\cdots \cdots \cdot-$ \\
\hline Hydrolysis of: & \\
\hline Case &. \\
\hline Sela &. \\
\hline DNA & + \\
\hline 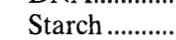 & $\ldots . . . \mathrm{w}$ \\
\hline Nitrate reduct & \\
\hline
\end{tabular}

${ }^{a}-$, negative reaction; + , positive reaction; $\mathrm{w}$, weakly positive reaction.

DNA base composition. The DNA base composition of " $C$. psychrophilum" JCM $1463^{\mathrm{T}}$ was $65 \mathrm{~mol} \% \mathrm{G}+\mathrm{C}$ by the HPLCnucleoside method.

16S rDNA sequence analysis. The $16 \mathrm{~S}$ rDNA of " $C$. psychrophilum" JCM $1463^{\mathrm{T}}$ was determined for 1,501 bases, as shown in the DDBJ database under accession number D45058. The sequence showed high similarities to those of actinomycetes with group B peptidoglycan, and the phylogenetic tree created with the representative strains is shown in Fig. 2. This organism was positioned in the cluster of actinomycetes with group B peptidoglycan but isolated from any of the subclusters corresponding to the established genera.

\section{DISCUSSION}

An obligately psychrophilic gram-positive bacterium, " $C$. psychrophilum" JCM $1463^{\mathrm{T}}$, showed interesting and unique characteristics, particularly in the cellular fatty acid profile. The presence of a significant amount of 12-methyl pentadecenoic acid (i.e., a-15:1) is characteristic for the cellular fatty acids of " $C$. psychrophilum" JCM $1463^{\mathrm{T}}$. The cellular fatty acid profile of this organism is principally the anteiso- and isobranched type, which is frequently found in gram-positive bacteria $(11,12,24)$. In this type of cellular fatty acid, a-15:0, the melting point is low enough to maintain the fluidity of the membrane as monounsaturated acids do in the straight-chain type (12). Therefore, generally trace or smaller amounts of unsaturated acids are found in this type of cellular fatty acid of mesophilic bacteria $(11,12,25)$. Even though unsaturated fatty acids have been found in some psychrophilic bacilli, they were straight-chain monounsaturated fatty acids $(2,10)$. Although Stead et al. reported that the ratio of a-15:1 accounted for approximately $10 \%$ in the cells of the strains of Clavibacter michiganensis subsp. sepedonicus (23), our analysis of the type strain of this subspecies showed a cellular fatty acid composition containing a-15:1 in 1\% of the acids (unpublished data).

The presence of a-15:1 is unusual but reasonable for psychrophilic gram-positive bacteria such as " $C$. psychrophilum" JCM $1463^{\mathrm{T}}$ to maintain membrane fluidity even at low temperatures. The amount of a-15:1 was increased by cultivation at lower temperatures, as shown in Table 1 . The cells of some mesophilic Curtobacterium strains grown at $10^{\circ} \mathrm{C}$ also contained a-15:1 acid as shown in Table 1. Although unusually low temperature was employed for cultivation of these strains, which grew optimally at 25 to $30^{\circ} \mathrm{C}(7,14)$, the amount of a-15:1 was so small ( $8 \%$ at the utmost) that they could not show a composition similar to that of "C. psychrophilum" JCM $1463^{\mathrm{T}}$. This fact indicates the distinctiveness of " $C$. psychrophilum" JCM $1463^{\mathrm{T}}$. The shift of cellular fatty acid composition in mesophilic anteiso-dominant bacteria is observed as the increase in the ratio of a-15:0 to a-17:0 in response to the change of cultivation temperature from $37^{\circ} \mathrm{C}$ to $20^{\circ} \mathrm{C}$ and not as the appearance of anteiso monounsaturated acids (25). The increase in the proportion of unsaturated straight-chain fatty acids was observed in psychrophilic gram-negative bacteria (5)

The diamino acid in the peptidoglycan of "C. psychrophilum" JCM $1463^{\mathrm{T}}$ was DAB instead of ornithine as reported previously (9). The molar ratio of amino acids was almost similar to those of the strains of the known DAB-containing genera, Agromyces, Clavibacter, and Rathayibacter (4, 22, 26), and was different from those of Agrococcus jenensis (6) and Leucobacter komagatae (27). Therefore, the peptidoglycan structure of this organism can be estimated to be that of B2 $\gamma$ of Schleifer and Kandler (22). Comparison of the ratio with that of Agromyces ramosus JCM $3108^{\mathrm{T}}$ (glutamic acid to alanine to glycine to $\mathrm{DAB}=1.0: 0.8: 1.1: 1.8)(4,26), " C$. psychrophilum" JCM $1463^{\mathrm{T}}$ contains a rather low level of alanine and $\mathrm{DAB}$. The substitute ratio of positions 3 (DAB) and 4 (alanine) of the peptide subunit might be relatively low. The cell wall acyl type of this strain was an acetyl type like that of the other DAB-containing taxa.

The major MK of "C. psychrophilum" JCM $1463^{\mathrm{T}}$ is MK-10 with significant amounts of MK-8 and MK-11. Although the strains of the genus Rathayibacter also possess MK-10 as the predominant MK, the composition is mostly MK-10, unlike in "C. psychrophilum" JCM $1463^{\mathrm{T}}$. The polar lipid profile of " $C$. 


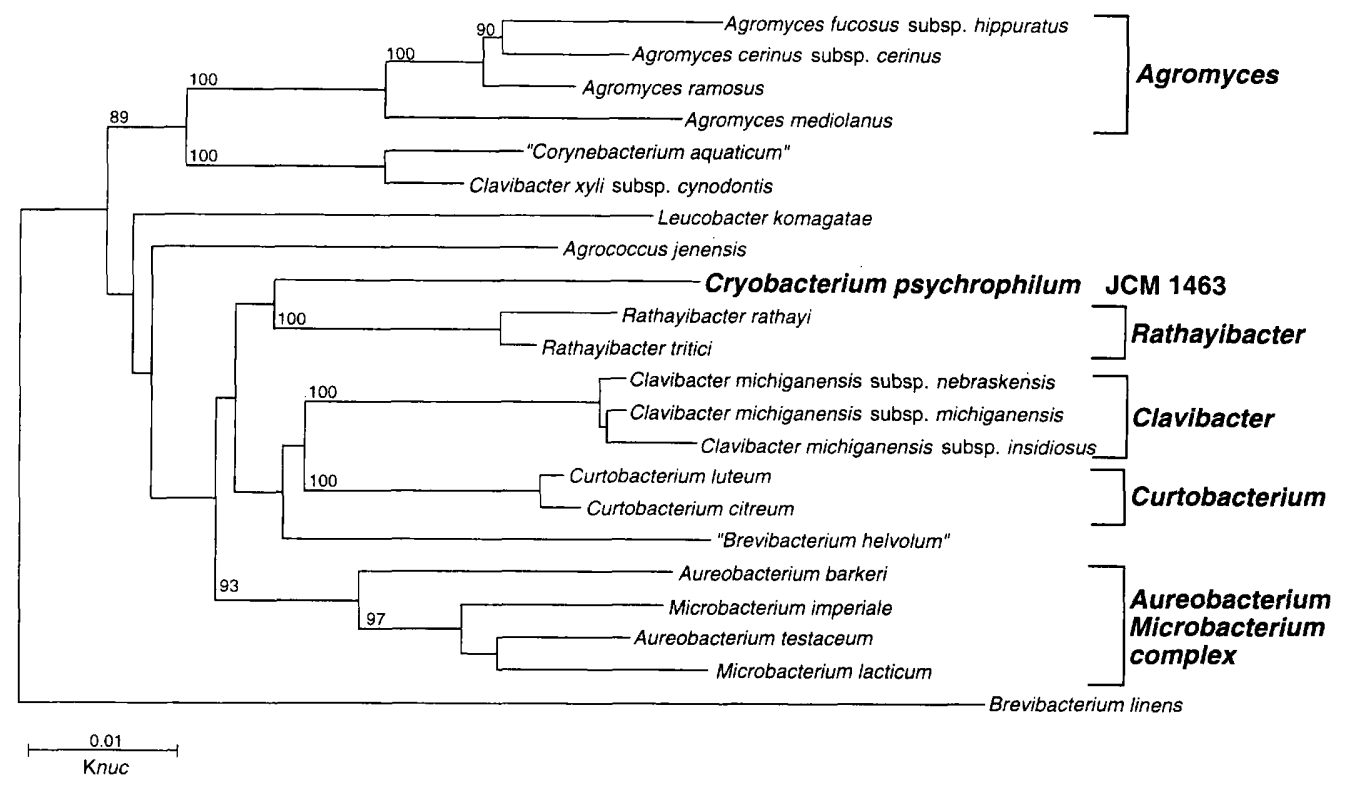

FIG. 2. Unrooted phylogenetic tree derived from $16 \mathrm{~S}$ rDNA sequences. The tree was created by using the neighbor-joining method and $K_{\text {nuc }}$ values. The numbers on the tree indicate bootstrap values (percent) for the branch points. The strains used and the nucleotide sequence accession numbers are indicated in the text.

psychrophilum" JCM $1463^{\mathrm{T}}$, consisting of diphosphatidylglycerol, phosphatidylglycerol, and glycolipid, is identical to those of the strains of the genera Agromyces, Clavibacter, and Rathayibacter $(1,3,33,34)$, except for the variation in the number of spots corresponding to glycolipids.

The cell wall sugar profile of " $C$. psychrophilum" JCM $1463^{\mathrm{T}}$ is distinct in the presence of fucose and rhamnose. Takeuchi and Yokota reported the presence of fucose in only one strain of Clavibacter michiganensis subsp. michiganensis among the coryneform bacteria which they studied (29). However, it is different from "C. psychrophilum" JCM $1463^{\mathrm{T}}$ in containing a significant amount of galactose. The cell wall of " $C$. psychrophilum" JCM $1463^{\mathrm{T}}$ is clearly differentiated from Rathayibacter strains in containing a large amount of fucose, which is lacking in the cell wall of Rathayibacter strains (34).

The phylogenetic analysis of "C. psychrophilum" JCM $1463^{\mathrm{T}}$ based on 16S rDNA sequences revealed that this organism was accommodated in the cluster corresponding to actinomycetes with group B peptidoglycan, i.e., the family Microbacteriaceae $(18,19,29)$. In the cluster of Microbacteriaceae, DAB-containing taxa such as Agrococcus, Agromyces, Clavibacter, Leucobacter, and Rathayibacter formed independent subclusters corresponding to the genera $(6,19,26)$. " $C$. psychrophilum" JCM $1463^{\mathrm{T}}$ showed a lineage independent from that of any of the genera in the cluster Microbacteriaceae.

The results of analyses of the biochemical and physiological characteristics of "C. psychrophilum" JCM $1463^{\mathrm{T}}$ were similar to those of the previous report by Inoue and Komagata (9), except for the acid from sucrose and glycerol and assimilation of formate.

On the basis of the data described above, we conclude that "C. psychrophilum" JCM $1463^{\mathrm{T}}$ should belong to a new genus in the family Microbacteriaceae. No strain other than the strain first isolated by Inoue and Komagata has been known. However, considering the unusual properties of the organism as shown above and the difficulty of reproducible isolation, we propose here a new genus, Cryobacterium, for " $C$. psychrophilum" JCM $1463^{\mathrm{T}}$ and propose that it be renamed as Cryobacterium psychrophilum gen. nov., sp. nov., nom. rev., comb. nov.
Description of Cryobacterium gen. nov. Cryobacterium (Cry.o.bac.te'ri.um Gr. n. kryos, cold; Gr. n. bakterion, a small rod; M. L. neut. n. Cryobacterium, a cold [preferring] rod) Pleomorphic nonmotile rod. Non endospore forming. Branching occurs in the early growth phase. Rod forms occur in old culture. Occasionally gram variable in the old culture. Grows optimally at 9 to $12^{\circ} \mathrm{C}$ and not at $18^{\circ} \mathrm{C}$. Aerobic. DNase and catalase are positive. Gelatin and casein are not hydrolyzed. Acid is produced from several sugars. The $\mathrm{G}+\mathrm{C}$ content of DNA is approximately $65 \mathrm{~mol} \%$. The amino acids of cell wall peptidoglycan are 2,4-diaminobutyric acid, alanine, glycine, and glutamic acid. Rhamnose and fucose are the characteristic cell wall sugars. The main cellular fatty acids are iso- and anteiso-branched acids. A significant amount of 12-methyl tetradecenoic acid (anteiso-C15:1) is contained. The major MK is MK-10. Mycolic acids are absent. The polar lipids are diphosphatidylglycerol, phosphatidylglycerol, and glycolipid.

The type species is $C$. psychrophilum.

Description of Cryobacterium psychrophilum sp. nov., nom. rev., comb. nov. (basonym "Curtobacterium psychrophilum" Inoue and Komagata 1976). Cryobacterium psychrophilum (psy. chro'phi.lum. Gr. adj. psychros, cold; Gr. adj. philus, loving; M. L. fem. adj. psychrophilum, cold loving). Nonmotile, non-endospore-forming, pleomorphic rod 0.5 to $0.7 \mu \mathrm{m}$ by 1.0 to 1.8 $\mu \mathrm{m}$ in culture on $\mathrm{R}$ agar for 5 days at $10^{\circ} \mathrm{C}$. Circular, opaque pink colonies are formed in 5 days of culture on $\mathrm{R}$ agar at $10^{\circ} \mathrm{C}$. Branching occurs in the early growth phase. Rod forms occur in old culture. Occasionally gram variable in the old culture. Aerobic. DNase and catalase are positive. Acid is produced from fructose, mannose, glucose, galactose, and sucrose but not from arabinose, mannitol, and glycerol. Lactate, pyruvate, fumarate, and hippurate are utilized. Gelatin and casein are not hydrolyzed. The $\mathrm{G}+\mathrm{C}$ content of the DNA is $65 \mathrm{~mol} \%$. 2,4-Diaminobutyric acid, alanine, glycine, and glutamic acid are the component amino acids of cell wall peptidoglycan, in the ratio 1.3:0.6:1.0:1.0. Rhamnose and fucose are the characteristic cell wall sugars. The main cellular fatty acids are isoand anteiso-branched acids. 12-Methyl tetradecenoic acid (aC15:1) accounts for approximately $20 \%$ of the cellular fatty 
acids in cells grown at $10^{\circ} \mathrm{C}$. The $\mathrm{MK}$ composition is predominantly MK-10, followed by MK-11 and MK-8. The polar lipids are diphosphatidylglycerol, phosphatidylglycerol, and glycolipid. The type strain of $C$. psychrophilum is JCM $1463(=\mathrm{K}$. Inoue and K. Komagata 27-O-b =IAM $12024=$ ATCC 43563 $=$ IFO $15735=$ NCIMB 2068).

\section{ACKNOWLEDGMENT}

We thank Masao Chijimatsu, Division of Biomolecular Characterization, The Institute of Physical and Chemical Research (RIKEN), for analyzing amino acids.

\section{REFERENCES}

1. Collins, M. D., and D. Jones. 1980 . Lipids in the classification and identification of coryneform bacteria containing peptidoglycan based on 2,4-diaminobutyric acid. J. Appl. Bacteriol. 48:459-470.

2. Dart, R. K., and T. Kaneda. 1970 . The production of $\Delta^{10}$-monounsaturated fatty acids by Bacillus cereus. Biochim. Biophys. Acta 218:189-194.

3. Davis, M. J., A. G. Gillaspie, Jr., A. K. Vidaver, and R. W. Harris. 1984. Clavibacter: a new genus containing some phytopathogenic coryneform bacteria, including Clavibacter xyli subsp. xyli sp. nov., subsp. nov, and Clavibacter xyli subsp. cynodontis subsp. nov., pathogens that cause ratoon stunting disease of sugarcane and Bermudagrass stunting disease. Int. J. Syst. Bacteriol. 34:107-117.

4. Fiedler, F., and O. Kandler. 1973. Die Aminosäuresequenz von 2,4-Diaminobuttersäure enthaltenden Mureinen bei verschiedenen coryneformen Bakterien und Agromyces ramosus. Arch. Mikrobiol. 89:51-66.

5. Fukunaga, N., and N. J. Russel. 1990. Membrane lipid composition and glucose uptake in two psychrotolerant bacteria from Antarctica. J. Gen. Microbiol. 136:1669-1673.

6. Groth, I., P. Schumann, N. Weiss, K. Martin, and F. A. Rainey. 1996. Agrococcus jenensis gen. nov., sp. nov., a new genus of actinomycetes with diaminobutyric acid in the cell wall. Int. J. Syst. Bacteriol. 46:234-239.

7. Iizuka, H., and K. Komagata. 1965. Microbiological studies on petroleum and natural gas. III. Determination of Brevibacterium, Arthrobacter, Micrococcus, Sarcina, Alcaligenes, and Achromobacter isolated from oil-brines in Japan. J. Gen. Appl. Microbiol. 11:1-14.

8. Inoue, K. 1976. Quantitative ecology of microorganisms of Showa Station in Antarctica and isolation of psychrophiles. J. Gen. Appl. Microbiol. 22:143150.

9. Inoue, K., and K. Komagata. 1976. Taxonomic study on obligately psychrophilic bacteria isolated from Antarctica. J. Gen. Appl. Microbiol. 22:165176.

10. Kaneda, T. 1971. Major occurrence of $c i s-\Delta^{5}$ fatty acids in three psychrophilic species of Bacillus. Biochem. Biophys. Res. Commun. 43:298-302.

11. Kaneda, T. 1977. Fatty acids of the genus Bacillus: an example of branchedchain preference. Bacteriol. Rev. 41:391-418.

12. Kaneda, T. 1991. Iso- and anteiso-fatty acids in bacteria: biosynthesis, function, and taxonomic significance. Microbiol. Rev. 55:288-302.

13. Kimura, M., and T. Ohta. 1972. On the stochastic model for estimation of mutation distance between homologous proteins. J. Mol. Evol. 2:87-90.

14. Komagata, K., and H. lizuka. 1964. New species of Brevibacterium isolated from rice (studies on the microorganisms of cereal grains. Part VII). Nippon Nogeikagaku Kaishi 38:496-502. (In Japanese.)

15. Komagata, K., and K. Suzuki. 1987. Lipid and cell wall analysis in bacterial systematics. Methods Microbiol. 19:161-208.

16. Lambert, M. A., and C. W. Moss. 1989. Cellular fatty acid compositions and isoprenoid quinone contents of 23 Legionella species. J. Clin. Microbiol. 27:465-473.

17. Minnikin, D. E., A. G. O'Donnell, M. Goodfellow, G. Alderson, M. Athalye,
A. Schaal, and J. H. Parlett. 1984. An integrated procedure for the extraction of bacterial isoprenoid quinones and polar lipids. J. Microbiol. Methods 2:233-241.

18. Park, Y. H., K. Suzuki, D. G. Yim, K. C. Lee, E. Kim, J. Yoon, S. Kim, Y. H. Kho, M. Goodfellow, and K. Komagata. 1993. Suprageneric classification of peptidoglycan group B actinomycetes by nucleotide sequencing of $5 \mathrm{~S}$ ribosomal RNA. Antonie Leeuwenhoek 64:307-313.

19. Rainey, F., N. Weiss, H. Prauser, and E. Stackebrandt. 1994. Further evidence for the phylogenetic coherence of actinomycetes with group B-peptidoglycan and evidence for the phylogenetic intermixing of the genera $\mathrm{Mi}$ crobacterium and Aureobacterium as determined by $16 \mathrm{~S}$ rDNA analysis. FEMS Microbiol. Lett. 118:135-140.

20. Saito, H., and K. Miura. 1963. Preparation of transforming deoxyribonucleic acid by phenol treatment. Biochim. Biophys. Acta 72:619-629.

21. Saitou, N., and M. Nei. 1987 . The neighbor-joining method: a new method for reconstructing phylogenetic trees. Mol. Biol. Evol. 4:406-425.

22. Schleifer, K. H., and O. Kandler. 1972. Peptidoglycan types of bacterial cell walls and their taxonomic implications. Bacteriol. Rev. 36:407-477.

23. Stead, D. E., J. E. Sellwood, J. Wilson, and I. Viney. 1992. Evaluation of a commercial microbial identification system based on fatty acid profiles for rapid, accurate identification of plant pathogenic bacteria. J. Appl. Bacteriol. 72:315-321.

24. Suzuki, K., M. Goodfellow, and A. G. O'Donnell. 1993. Cell envelopes and classification, p. 195-250. In M. Goodfellow and A. G. O'Donnell (ed.) Handbook of new bacterial systematics. Academic Press, London, United Kingdom.

25. Suzuki, K.-I., and K. Komagata. 1983. Taxonomic significance of cellular fatty acid composition in some coryneform bacteria. Int. J. Syst. Bacteriol. 33:188-200.

26. Suzuki, K.-I., J. Sasaki, M. Uramoto, T. Nakase, and K. Komagata. 1996. Agromyces mediolanus sp. nov., nom. rev., comb. nov., a species for "Conynebacterium mediolanum" Mamoli 1939 and for some aniline-assimilating bacteria which contain 2,4-diaminobutyric acid in the cell wall peptidoglycan. Int. J. Syst. Bacteriol. 46:88-93.

27. Takeuchi, M., N. Weiss, P. Schumann, and A. Yokota. 1996. Leucobacter komagatae gen. nov., sp. nov., a new aerobic gram-positive, nonsporulating rod with 2,4-diaminobutyric acid in the cell wall. Int. J. Syst. Bacteriol. 46:967-971.

28. Takeuchi, M., and A. Yokota. 1989. Cell wall polysaccharides in coryneform bacteria. J. Gen. Appl. Microbiol. 35:233-252.

29. Takeuchi, M., and A. Yokota. 1994. Phylogenetic analysis of the genus Microbacterium based on 16S rRNA gene sequences. FEMS Microbiol. Lett. 124:11-16.

30. Tamaoka, J., and K. Komagata. 1984. Determination of DNA base composition by reversed-phase high-performance liquid chromatography. FEMS Microbiol. Lett. 25:125-128.

31. Thompson, J. D., D. G. Higgins, and T. J. Gibson. 1994. CLUSTAL W improving the sensitivity of progressive multiple sequence alignment through sequence weighting, position specific gap penalties and weight matrix choice. Nucleic Acids Res. 22:4673-4680.

32. Yamada, K., and K. Komagata. 1972. Taxonomic studies on coryneform bacteria. IV. Morphological, cultural, biochemical and physiological characteristics. J. Gen. Appl. Microbiol. 18:399-416.

33. Zgurskaya, H. I., L. I. Evtushenko, V. N. Akimov, H. V. Voyevoda, T. G. Dobrovolskaya, L. V. Lysak, and L. V. Kalakoutskii. 1992. Emended description of the genus Agromyces and description of Agromyces cerinus subsp. cerinus sp. nov., subsp. nov., Agromyces cerinus subsp. nitratus sp. nov., subsp. nov., Agromyces fucosus subsp. fucosus sp. nov., subsp. nov., Agromyces fucosus subsp. hippuratus sp. nov. subsp. nov. Int. J. Syst. Bacteriol. 42:635-641.

34. Zgurskaya, H. I., L. I. Evtushenko, V. N. Akimov, and L. V. Kalakoutskii 1993. Rathayibacter gen. nov., including the species Rathayibacter rathayi comb. nov., Rathayibacter tritici comb. nov., Rathayibacter iranicus comb. nov., and six strains from annual grasses. Int. J. Syst. Bacteriol. 43:143-149. 